\title{
Remote hypofluorescent dots in recurrent ocular toxoplasmosis on indocyanine green angiography
}

\author{
Pontos hipofluorescentes remotos em toxoplasmose ocular recorrente na \\ angiografia com indocianina verde
}

\author{
Miguel Hage Amaro ${ }^{1}$ \\ Cristina Muccioli ${ }^{2}$ \\ Mariza Toledo Abreu $^{3}$ \\ Rubens Belfort Jr. ${ }^{4}$
}

\begin{tabular}{|l|}
\hline ABSTRACT \\
\hline Purpose: To report the findings of indocyanine green angiography \\
performed in patients with recurrent ocular toxoplasmosis. Methods: \\
Institutional prospective analysis of 23 eyes from 23 immunocompetent \\
patients with recurrent ocular toxoplasmosis aged between 17 and 41 \\
years. These patients underwent a complete ocular examination including \\
indocyanine green angiography. Results: Multiple hypofluorescent \\
spots distant from the recurrent active lesion of retinochoroidal toxo- \\
plasmosis were found in $26.08 \%$ of the patients. We also found multiple \\
hypofluorescent satellite dots in $69.56 \%$ of the patients. Conclusion: \\
These remote dots seen suggest either a more widespread choroidal \\
involvement inthis disease and this can represent simply remotecollections \\
of inflammatory cells or subclinical infection.
\end{tabular}

Keywords: Toxoplasmosis, ocular/diagnosis; Choroiditis; Fluorescein angiography; Indocyanine green/diagnostic use; Retinitis; Recurrence

\section{INTRODUCTION}

Toxoplasmosis is a common disease that occurs worldwide in birds and warm-blooded mammals including humans ${ }^{(1)}$. It is caused by infection of a single-celled parasite called Toxoplasma gondii ${ }^{(1)}$.

Toxoplasma gondii infection is a frequent cause of uveitis ${ }^{(1-5)}$. Toxoplasma gondii is an obligate intracellular parasite and infection is widespread in nature.

Human toxoplasmosis may occur in either a congenital or an acquired form. Serologic evidence of previous Toxoplasma gondii infection is present in $20 \%$ to $70 \%$ of the population of the United States of America $^{(6-7)}$.

Toxoplasma gondii is a coccidian classified as belonging to the phylum Apicomplexa, class Sporozoa, order Eucoccidia and suborder Eimeria. The infection is a zoonosis and members of the cat family are the definitive hosts ${ }^{(8-17)}$.

Acute systemic toxoplasmosis in normal hosts is most often a subclinical infection but may present as a mild flu-like illness. The disease is controlled by the host's immune response to the acute infection. If the parasite reaches the eye, a focus of infection is established, which progresses from mainly a retinitis with some spillover inflammation into the adjacent choroid and vitreous ${ }^{(1)}$.

It is estimated that about two-thirds of patients with toxoplasmosis have recurrent episodes of inflammation ${ }^{(18)}$. Various mechanisms have been hypothesized as the cause of recurrent inflammatory episodes including: (1) 
reactivation of Toxoplasma gondii cysts within the retina; (2) an autoimmune response to remaining retinal antigen; and (3) reinfection with live organisms. The first two mechanisms are supported by the observation that recurrent lesions frequently develop at the borders of old retinochoroidal scars ${ }^{(18)}$.

Indocyanine green angiography (ICG) has been used to study inflammatory chorioretinal diseases ${ }^{(19-20)}$ and toxoplasmosis ${ }^{(21-23)}$.

In toxoplamosis, recurrent active retinal lesions on fluorescein angiography present hypofluorescence in the center and staining of the dye on the edge of the lesions of acute recurrent active retinitis ${ }^{(2)}$.

On indocyanine green angiography, recurrent active retinal lesions are hypofluorescent in all phases of the study. Satellite dark dots have been described around the hypofluorescent recurrent active lesion ${ }^{(21)}$.

We analyzed a case series of patients with recurrent ocular toxoplasmosis using ICG angiographic studies and sought to present the respective findings in this study.

\section{METHODS}

This is an Institutional prospective study. The study protocol was approved by the Medical Research Ethics Commitee of Universidade Federal de São Paulo (Escola Paulista de Medicina). We evaluated 23 eyes of 23 immunocompetent patients, between January 2001 and June 2004. There were 10 females and 13 males with age ranging from 17 to 41 years, with a mean age of 29. All patients had unilateral recurrent toxoplasmic retinitis, at the time of diagnosis.

Presentation of recurrent retinitis was classified in the moment the patients were diagnosed ${ }^{(23)}$. According to this classification, the presentation of recurrent retinitis can be one of the following: (1) large destructive lesions (in which active retinitis involves an area usually larger than the optic nerve head); (2) punctate inner retinal lesions (gray area of active retinitis with minimal edema and vitreous reaction) and; (3) punctuate outer retinal lesions. The patients underwent an ocular examination including fluorescein angiography and indocyanine green angiography, focusing on the recurrent active retinal lesion, the surrounding area and other areas in the ocular fundus. These tests were performed at the time of diagnosis; with the improvement of inflammation and; after healing of the recurrent active lesion. All patients were treated for six weeks with oral antitoxoplasmic drugs, such as sulfadiazine and pyrimethamine, and folinic acid. Oral prednisone $20 \mathrm{mg} /$ day was also administered in half of the patients if they presented vitreous inflammation, or if the recurrent lesion was located in the posterior pole of the eye, close to the macular region.

\section{RESULTS}

Fluorescein angiography showed hypofluorescence in the center and staining of the dye on the edge of the retinal recurrent active lesion in all patients.
ICG angiography showed multiple hypofluorescent dots surrounding the active lesions in $70 \%$ of the eyes (Figure 1). In $26 \%$ of the eyes (six patients) hypofluorescent dots (Figures 2 and 3) were also seen in areas of the fundus distant from the active recurrent lesion and in areas of retina that appeared normal on fundoscopy and fluorescein angiography at the moment of the diagnosis.

They are noticed in all the three morphologic variations of retinitis presentation. The remote dots were found in six patients and three of them were treated with antitoxoplasmic drugs plus steroid and the other three patients were treated with antitoxoplasmic drugs alone. Both the adjacent and remote hypofluorescent spots disappeared after treatment and control of the active inflammation.

\section{DISCUSSION}

Researchers agree that patients have a life-long risk of recurrences. A steady rise in the cumulative prevalence of patients who have had disease recurrences ${ }^{(24)}$ was demonstrated. However, other authors ${ }^{(23)}$ found that the frequency of recurrence drops in many patients after a few years, and that they eventually cease to occur. This decline in the frequency of recurrences could be related to host factors, either involving sequestration of tissue cysts or improved immunological control of infection. The latter possibility is unlikely, however, in view of the fact that immune defenses are believed to decline with age. As a result, ocular diseases may actually be more severe in older patients. Another possibility is that tissue cysts have a finite lifespan in human hosts, and that patients will eventually have no tissue cysts that could reactivate. It is unlikely that this pattern of recurrences is the result of therapy, since there has been no demonstrable effect of short-term treatment on the intervals to first recurrences.

A study ${ }^{(23)}$ suggested that recurrences can develop in clusters, and that there can be long intervals between clusters. A theory ${ }^{(18)}$ for this is that the clustering effect might be explained by the fact that, with a given recurrence, the local number of tissue cysts increases through proliferation of organisms during the active phase of disease, thereby increasing the likelihood that at least one tissue cyst will subsequently reactivate. The risk of recurrences would again drop over time, as tissue cysts became nonviable; eventually, some disorder of host defenses would allow another episode if any viable tissue remained in the retina, then the number of tissue cysts would increase again, thereby initiating another cycle of frequent recurrences.

In conclusion, our study shows intriguing findings when observing the results of ICG angiography in a case series of recurrent ocular toxoplasmosis, despite the fact that multiple hypofluorescent dots have been previously seen in inflammatory chorioretinal diseases ${ }^{(19-20)}$. In ocular toxoplasmosis the most common finding is the occurrence of hypofluores- 


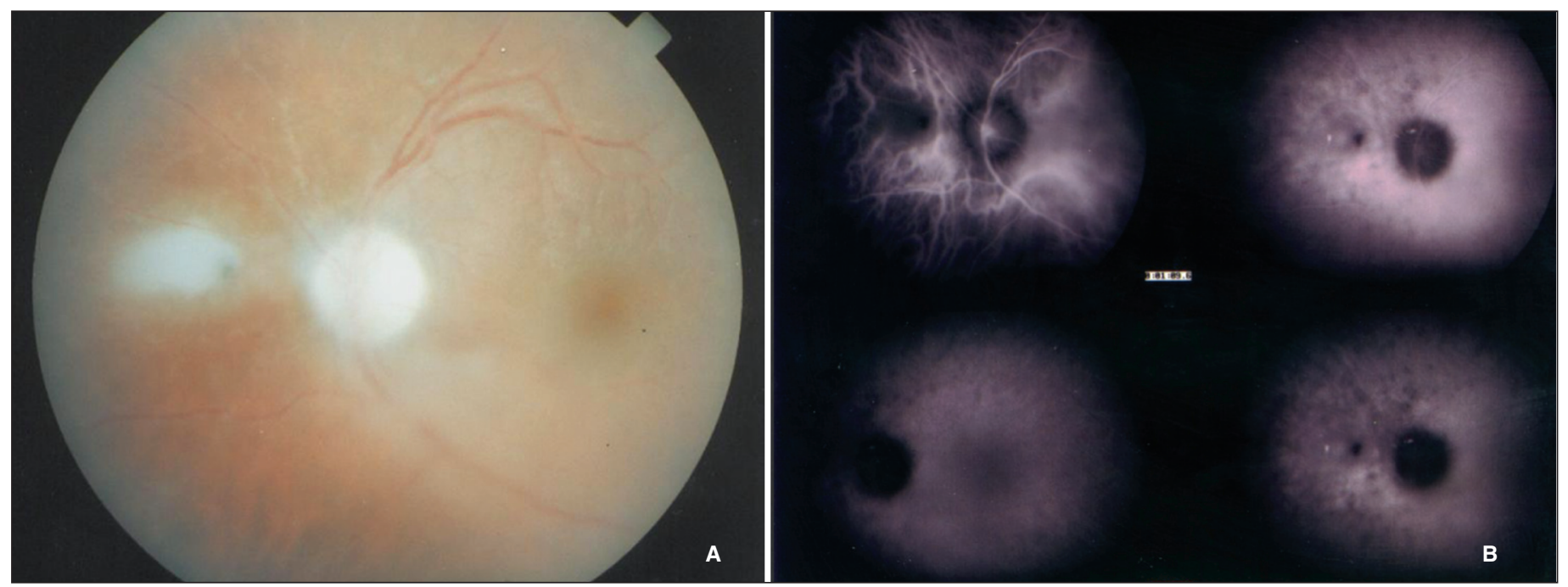

Figure 1- A) Nasal recurrent active toxoplasmosis; B) Satellite dark dots
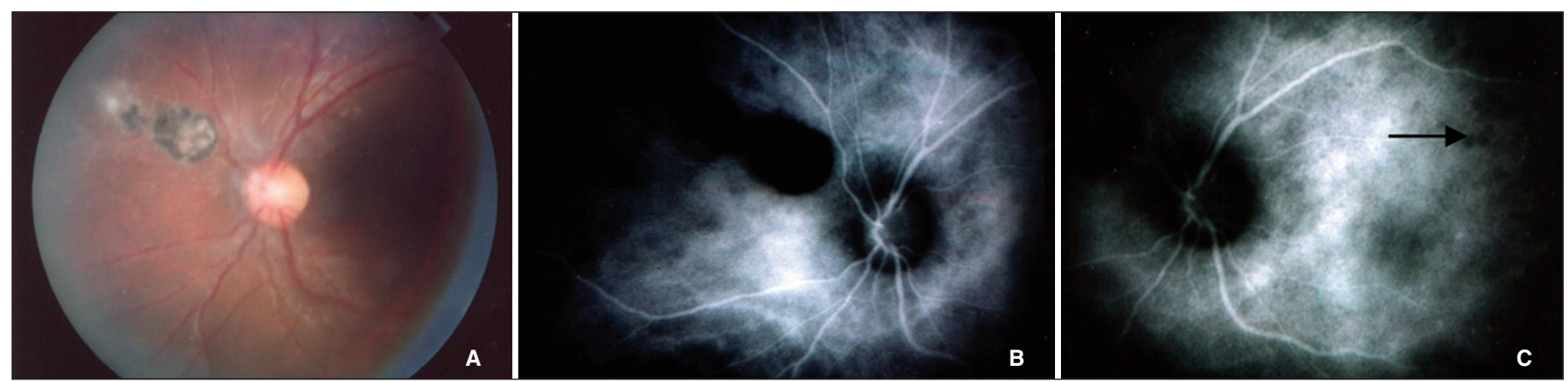

Figure 2 - A) Nasal recurrent active toxoplasmosis; B) Satellite dark dots; C) Remote dots temporal to the macula (marked by the arrowhead)

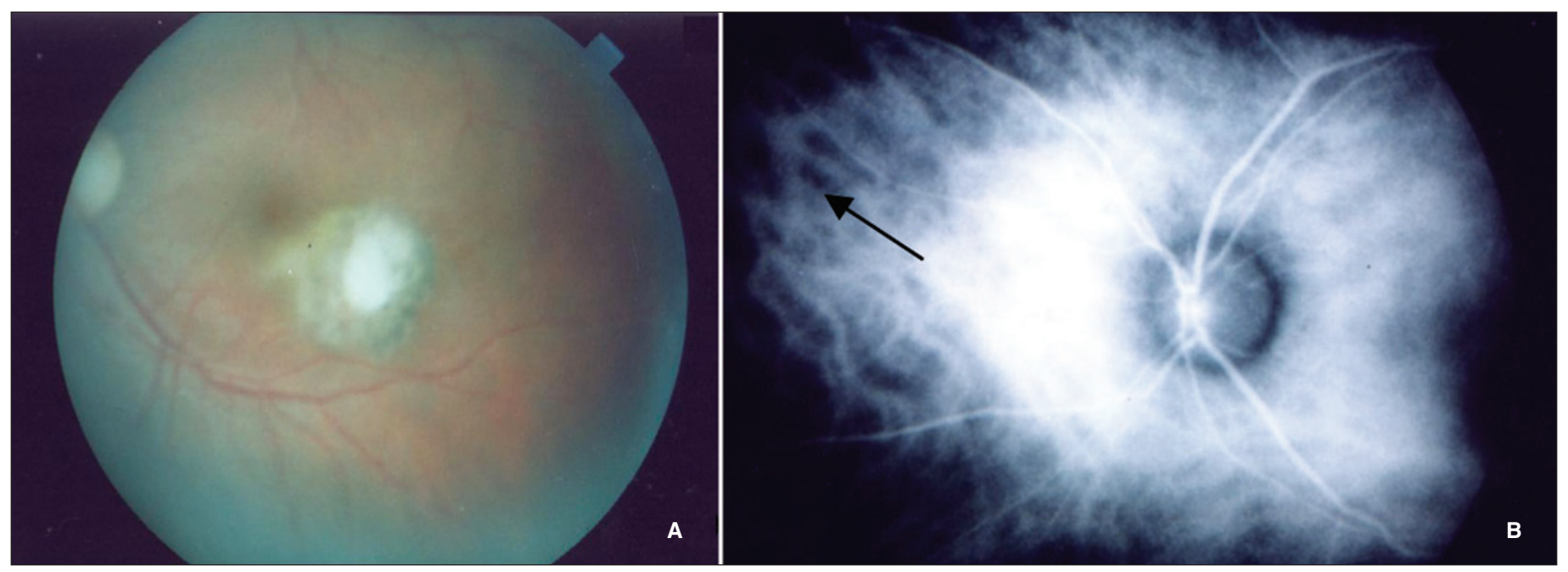

Figure 3 - A) Juxtamacular recurrent active toxoplasmosis; B) Remote dots in the nasal region (marked by the arrowhead)

cent dots surrounding the active lesions called satellite dark dots, which were seen in approximately $75 \%$ of the cases in a small case series ${ }^{(21-2)}$. It was hypothesized that these hypofluo- rescent dots represent additional areas of infection because they progressed to white lesion in two cases ${ }^{(26)}$. We also found hypofluorescent dots around the active lesions. In addition, 
however, there were hypofluorescent dots distant from active recurrent lesions in areas that appeared normal on fundoscopy and fluorescein angiography. These remote dots were seen in $26 \%$ of the eyes in our case series.

\section{CONCLUSION}

The presence of these remote dots suggests either a more widespread infectious disease than suspected or perhaps just sterile choroidal inflammation as a general response to intraocular inflammation. We believe that ICG angiography allowed us to observe results in cases of recurrent ocular toxoplasmosis that had not been previously observed. However, further studies will be necessary to elucidate the significance of these hypofluorescent remote dots.

\section{RESUMO}

Objetivos: Relatar os achados da angiografia com indocianina verde, realizados em pacientes com recidiva de toxoplasmose ocular. Métodos: Análise institucional e prospectiva de 23 olhos de 23 pacientes, imunocompetentes com idades entre 17 e 41 anos. Estes pacientes foram submetidos a exame oftalmológico de rotina e a angiografia com indocianina verde. Resultados: Foram encontrados múltiplos pontos hipofluorescentes distantes da lesão ativa recidivada da toxoplasmose retino-coroidiana em $26,08 \%$ dos casos, chamados por nós de pontos remotos e encontramos também, pontos hipofluorescentes circundando ou próximos da lesão ativa recidivada em $69,56 \%$ dos casos. Conclusão: Os pontos hipofluorescentes distantes da lesão ativa recidivada, chamados de pontos remotos, não descritos previamente na doença, demonstram um maior envolvimento da coróide e podem significar coleções remotas de células inflamatórias ou infecção subclínica.

Descritores:Toxoplasmose ocular/diagnóstico; Coroidite; Angiofluoresceinografia; Verde de indocianina/uso diagnóstico; Retinite; Recidiva

\section{REFERENCES}

1. Perkins ES. Ocular Toxoplasmosis. Br J Ophthalmol. 1973;57(1):1-17.
2. Gass JD. Stereoscopic atlas of macular diseases: diagnosis and treatment. $2^{\text {nd }}$ ed. St. Louis: Mosby; 1987.

3. Schlaegel Jr TF. Toxoplasmosis. In: Duane TD, Jaeger EA, editors. Clinical ophthalmology. Hagerstown, MD: Harper \& Row; 1978. vol.4.

4. Tabbara KF. Toxoplasmosis. In: Duane TD, Jaeger EA, editors. Clinical ophthalmology. Hagerstown, MD: Harper \& Row; 1978. vol.4.

5. Wilder HC. Toxoplasma chorioretinitis in adults. AMA Arch Ophthalmol. 1952;48(2):127-36.

6. Anderson S. Toxoplasma gondii. In: Mandell GL, Douglas RG Jr, Bennett JE, editors. Principles and practice of infectious diseases. New York: John Wiley; 1979.

7. McCabe RE, Remington JS. Toxoplasma gondii. In: Mandell GL, Douglas RG Jr. Bennett JE, editors. Principles and practice of infectious diseases, $2^{\text {nd }}$ ed. New York: John Wiley; 1985.

8. Cohen SN. Toxoplasmosis in patients receiving immunosuppressive therapy. JAMA. 1970;211(4):657-60.

9. Couvreur J, Desmonts G. Congenital and maternal toxoplasmosis. A review of 300 congenital cases. Dev Med Child Neurol. 1962;4:519-30.

10. Hoerni B, Vallat M, Durand M, Pesme D. Ocular toxoplasmosis and Hodgkin's disease: report of two cases. Arch Ophthalmol. 1978;96(1):62-3.

11. Nicholson DH, Wolchok EB. Ocular toxoplasmosis in an adult receiving long-term corticosteroid therapy. Arch Ophthalmol. 1976;94(2);248-54.

12. Reynolds ES, Walls KW, Pfeiffer RI. Generalized toxoplasmosis following renal transplantation. Report of a case. Arch Intern Med. 1966;118(4):401-5.

13. Ruskin J, Remington JS. Toxoplasmosis in the compromised host. Ann Intern Med. 1976;84(2):193-9. Review.

14. Krick JA, Remington JS. Toxoplasmosis in the adult an overview. N Engl J Med. 1978;298(10):550-3.

15. Miller NL, Frenkel JK, Dubey JP. Oral infections with Toxoplasma cysts and oocvsts in felines, other mammals, and in birds. J Parasitol. 1972;58(5): 928-37.

16. Swartzberg JE, Remington JS. Transmission of Toxoplasma. Am J Dis Child. 1975;129(7):777-9.

17. Teutsch SM, Juranek DD, Sulzer A, Dubey JP, Sikes RK. Epidemic toxoplasmosis associated with infected cats. N Engl J Med. 1979;300(13): 695-9.

18. Holland GN. Ocular toxoplasmosis: a global reassessment. Part I: epidemiology and course of disease. Am J Ophthalmol. 2003;136(6):973-88.

19. Slakter JS, Giovannini A. Multifocal choroiditis and the presumed ocular histoplasmosis syndrome. In: Yannuzzi LA, Flower RW, Slakter JS. Indocyanine green angiography. St Louis: Mosby; 1997. p.271-8.

20. Slakter JS, Giovannini A, Yannuzzi LA, Scassellati-Sforzolini B, Guyer DR, Sorenson JA, et al. Indocyanine green angiography of multifocal choroiditis. Ophthalmology. 1997;104(11):1813-9.

21. Auer C, Bernasconi O, Herbort CP. Toxoplasmic retinochoroiditis: new insights provided by indocyanine green angiography. Am J Ophthalmol. 1997; 123(1):131-3.

22. Da Mata AP, Orefice F. Toxoplasmosis. In: Foster S, Vitale A. Diagnosis and treatment of uveitis. Philadelphia: Saunders; 2002. p.385-410.

23. Friedmann CT, Knox DL. Variations in recurrent active toxoplasmic retinochoroiditis. Arch Ophthalmol. 1969;81(4):481-93.

24. Bosch-Driessen LE, Berendschot TT, Okngkosuwito JV, Rothova A. Ocular toxoplasmosis: clinical features and prognosis of 154 patients. Ophthalmology. 2002;109(5):869-78.

25. Auer $\mathrm{C}$, Bernasconi $\mathrm{O}$, Herbort $\mathrm{CP}$. Indocyanine green angiographic features in toxoplasmic retinochoroiditis. Retina. 1999;19(1):22-9.

26. Bernasconi O, Auer C, Herbort CP. Recurrent toxoplasmic retinochoroiditis. Significance of perilesional satellite dark dots: seen by indocyanine green angiography. Ocul Immunol Inflamm. 1997;5(3):207-11. 